\title{
Bacterial Diversity on the Application of Methanotrophic Bacteria in Rainfed Rice of Kupang Regency, East Nusa Tenggara, Indonesia
}

\author{
Rizki Adiputra Taopan ${ }^{1}$, Iman Rusmana ${ }^{2}$, and Dwi Andreas Santosa ${ }^{3}$ \\ \{rizkimicro@gmail.com ${ }^{1}$, irusmana@ipb.ac.id ${ }^{2}$, dsantosa@indo.net.id ${ }^{3}$ \} \\ Faculty of Health Science and Agricultural, Indonesian Catholic University of St Paul Ruteng, \\ Indonesia ${ }^{1}$, Faculty of Mathematics and Natural Resources, IPB University, Indonesia ${ }^{2}$, Faculty of \\ Agriculture, IPB University, Indonesia ${ }^{3}$
}

\begin{abstract}
Paddy fields are the main anthropogenic source of methane emissions as a greenhouse gas that causes global warming. In this research, methanotrophic bacteria as biological fertilizers are used to reduce methane gas in rainfed rice fields and study the diversity of bacteria based on the application of these fertilizers. This research began with the cultured of the bacterial cultures of Methylocystis rosea BGM 1, Methylocystis palvus BGM 3, M. capsulatus BGM 9 and Methylobacter sp. SKM 14. Furthermore, culture production and application are carried out in rainfed rice fields. The treatments consisted of: (1) NPK 100\% (P1), (2) NPK 50\% (P2), (3) without fertilizer application (P3), (4) NPK 100\% + Metanotrophs (P4), (5) NPK 50\% + Metanotrophs (P5), and (6) Metanotrophs (P6). Analysis of the diversity of bekteri using the Deanaturing Gradient Gel Eltrophoresis (DGGE) technique. The study of bacterial diversity based on the $16 \mathrm{~S}$ rRNA gene showed that the proteobacteria genus dominated the habitat consisting of the gammaproteobacteria, alfaproteobacteria and deltaproteobacteria classes.
\end{abstract}

Keywords: DGGE; Methanotroph; Methane emission; Rainfed rice

\section{Introduction}

Rice fields are a major anthropogenic wetland source of methane $(\mathrm{CH} 4)$ emissions causing global warming. Methane is derived from methanogenesis activity by methanotrophic bacteria [1]. [2] state that $80 \%$ of methane gas in rice fields can be oxidized by methanotrophic bacteria. Biofertilizers made from methanotrophic bacteria can be alternative mitigation of methane emissions in paddy fields. Methanotrophic bacterial isolates [3] include Methylocystis rosea BGM 1 and Methylobacter sp. SKM 14 has the pmoA gene. Besides, isolates of Methylococcus capsulatus BGM 9 have the mmoX gene [4] and Methylocystis palvus BGM 3 isolates and M. capsulatus BGM 9 have nifH and nifD genes that play a role in N2 inhibition [5]. Trials of these isolates on organic and inorganic paddy fields showed a reduction in methane gas up to $20.47 \%$ and effectively stimulate rice growth in the vegetative phase [6]; [7]). Experiments on lowland rice fields show the reduction of methane gas and stimulate rice growth in the vegetative and generative phases [8].

The application of methanotrophic bacteria in rainfed rice can increase rice productivity by $1.7 \mathrm{t} / \mathrm{ha}$ and reduce methane gas in the vegetative and generative phases [9]. Fertilization also affects the diversity of bacteria in an agricultural environment [10]. In this study, an 
analysis of bacterial diversity was performed using the Polymerase Chain Reaction Denaturing Gradient Gel Electrophoresis (PCR-DGGE) technique. DGGE is a technique for distinguishing species based on GC composition [11] and has been used in the analysis of bacterial diversity in certain environments.

\section{Method}

\subsection{Material}

The biofertilizer used in this study consisted of methanotrophic bacteria i.e. Methylocystis rosea BGM 1, Methylocystis parvus BGM 3, Methylococcus capsulatus BGM 9, and Methylobacter sp. SKM 14.

\subsection{Rice Field Experiment}

Ciherang rice varieties are grown in rainfed rice fields with treatment consist of (1) $100 \%$ NPK (P1), (2) 50\% NPK (P2), (3) without fertilizer application (P3), (4) $100 \%$ NPK + Metanotroph (P4)), (5) NPK 50\% + Metanotroph (P5), and (6) Metanotroph (P6). Each treatment has 4 replications.

\subsection{DNA Extraction and 16S rRNA Amplification}

Soil samples for DNA extraction taken from each treatment at 30, 60, and 90 Day After Planting (DAP). DNA extraction used PowerSoil® DNA Isolation Kit (Mobio Laboratories, Carlsbad, CA, USA). DNA concentration and purity were measured by spectrophotometric methods using Nano drop 2000 (Thermo Scientific, Wilmington, DE, USA). Amplification16S rRNA gene used P338F-GC primers (5'CGCCCGCCGCGCGCGGCGGGCGGGGCGGGGGGCACGGGGGGACTCCTACGGG AGGCAGCAG-3 ') and P518R (5' ATTACCGCGGCTGCTG-3') [12]. The total PCR volume is $30 \mu \mathrm{L}$, with a composition of $1.5 \mu \mathrm{L}$ reverse primer, $1.5 \mu \mathrm{L}$ forward primer, $11 \mu \mathrm{L}$ nuclease free water (NFW), $15 \mu \mathrm{L}$ GoTaq Green Mastermix 2x (Promega, Madison, USA), and $1 \mu \mathrm{L}$ DNA template. The amplification results electrophoresed on $1 \%$ agarose gel in a $1 \mathrm{X}$ TAE buffer (Tris-acetic acid-EDTA) with a voltage of $100 \mathrm{~V}$ for 35 minutes. The tape stained with ethidium bromide (EtBr) for 12 minutes and visualized with G: BOX Gel Documentation (Syngene, Frederick, USA).

\subsection{Denaturing Gradient Gel Electrophoresis (DGGE)}

Denaturing Gradient Gel Electrophoresis (DGGE) analysis used DCodeTM Universal Mutation Detection System (Bio-Rad, Hercules, CA, USA). A total of $31 \mu \mathrm{L}$ DNA templates $(26 \mu \mathrm{L}$ PCR amplicons $+5 \mu \mathrm{L}$ loading dye) migrated at $8 \%$ polyacrylamide gels. Polyacrylamide gels made from acrylamide: bis acrylamide (37.5: 1). The denaturant used formamide and urea with ratio 35: 65\%. DGGE conditions are $60^{\circ} \mathrm{C}$ with a voltage of $60 \mathrm{~V}$ for 12 hours. The polyacrylamide gel was then stained with EtBr for 15 minutes. Visualization is done using G: BOX Gel Documentation (Syngene, Frederick, USA). The results of the visualization then analyzed using Lab Image software. The DNA band that always appears at each treatment in each DAP then cut and inserted into $100 \mu \mathrm{L} \mathrm{NFW}$ for elution. 


\subsection{Nested PCR, Bioinformatic Study and Phylogenetic Tree Construction}

DNA bands have been cut then performed nested PCR using 338F / 518R primers without GC clamp. PCR conditions and composition are the same as before. DNA sequences obtained were compared with sequences available at NCBI (http://www.ncbi.nlm.nih.gov) and analyzed with the Mega 7 program for phylogenetic tree construction.

\subsection{Data Analysis}

OTU (Operational Taxonomic Unit) data at each DAP analyzed using multivariate clustering analysis and displayed in the dendrogram.

\section{Result and Discussion}

\subsection{DNA Extraction and 16S rRNA Amplification}

DNA extraction using Power Soil囚 DNA Isolation Kit (Mobio Laboratories, Carlsbad, CA, USA) produces DNA concentrations ranging from 11.95-54.3 $\mathrm{ng} / \mu \mathrm{L}$. A260/280 values indicate that the purity of DNA is relatively low, ranging from 0.9-1.6. Amplification of the $16 \mathrm{~S}$ rRNA gene using a 338F-GC/518R primary pair [12] produced an amplicon of $180 \mathrm{bp}$ in length (Figure 1). This primer is specific for amplifying the V3 region of 16S rRNA that is commonly used in DGGE analysis.

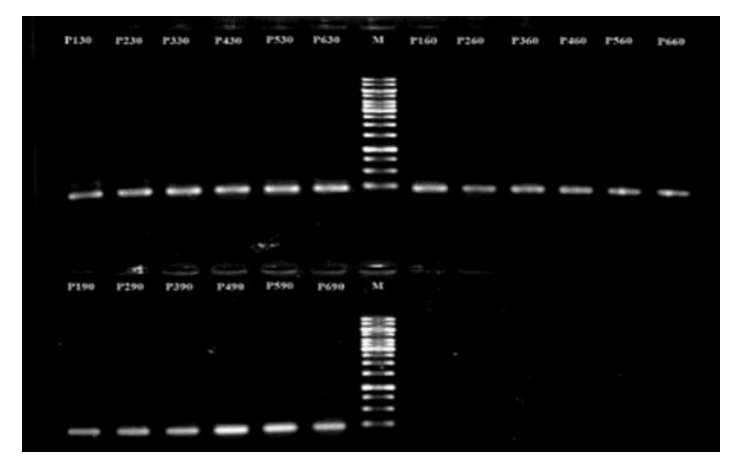

Fig 1. Visualization of 16S rRNA gene amplification using 338F-GC / 518R primers

\subsection{DGGE Profile}

Separate bands in the DGGE analysis of each DAP analyzed using multivariate clustering analysis and displayed in dendrogram. There were 5 bands in 30 DAP, whereas 60 and 90 DAP were 4 bands. The 30 DAP dendrogram (Figure 2c) forms 2 clades namely P4, P6, P1, P2, and P5 treatments form a separate clade, while the P3 treatment forms a separate clade. The 60 HST dendrogram (Figure 3c) forms 2 clades, namely treatments P4, P5, and P6 form separate clades with treatments P1 and P2. P3 treatment is included in the clade along with NPK fertilization treatment.

The 90 HST dendrogram forms 3 clades (Figure 4c), ie the P4, P5, P2, and P1 treatments are in the clade, while the $\mathrm{P} 3$ treatment forms a separate clade but still in the same cluster. The P6 treatment forms a single clade (simplicifolius clade). 


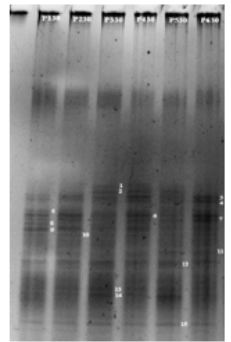

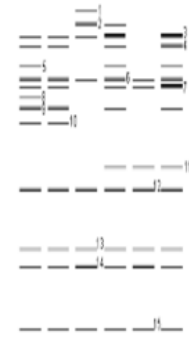

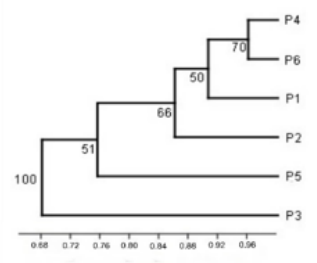

c

Fig 2. (a) DGGE profiles based on $16 \mathrm{~S}$ rRNA at 30 DAP. (b) Interpretation of results with the LabImage program. (c) Analysis of bacterial diversity clustering based on the 16S rRNA gene. Q1. NPK 100\%; P2. NPK 50\%; P3. Without fertilization; Q4. NPK 100\% + Metanotrof; Q5.

NPK 50\% + Metanotrof; Q6. Metanotroph

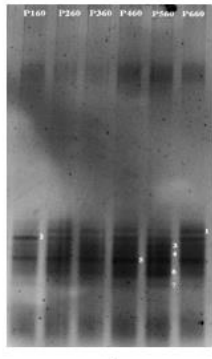

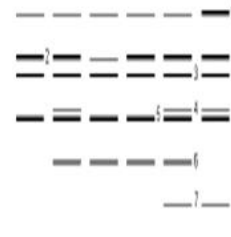

b

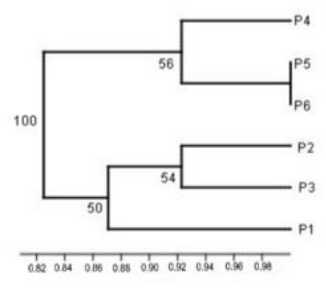

Fig 3. (a) DGGE profiles based on $16 \mathrm{~S}$ rRNA at 60 DAP. (b) Interpretation of results with the LabImage program. (c) Analysis of bacterial diversity clustering based on the 16S rRNA gene. Q1. NPK 100\%; P2. NPK 50\%; P3. Without fertilization; Q4. NPK 100\% + Metanotrof; Q5. NPK 50\% + Metanotrof; Q6. Metanotroph

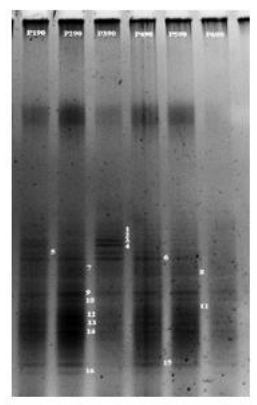

a

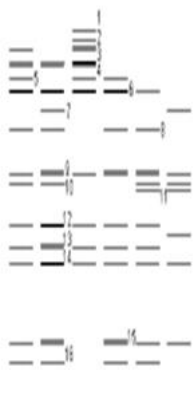

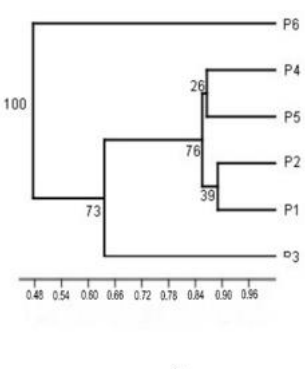

Fig 4. (a) DGGE profiles based on 16S rRNA at 90 DAP. (b) Interpretation of results with the LabImage program. (c) Analysis of bacterial diversity clustering based on the 16S rRNA gene. Q1. NPK 100\%; P2. NPK 50\%; P3. Without fertilization; Q4. NPK 100\% + Metanotrof; Q5.

NPK 50\% + Metanotrof; Q6. Metanotroph

\subsection{Nested PCR, Bioinformatic Study and Phylogenetic Tree Construction}

The cut DGGE tape then eluted for the nested PCR process using primers without GC clamp. A total of 11 bands were successfully amplified in the nested PCR process by producing a band size of $180 \mathrm{bp}$. BLAST-N analysis showed 6 DGGE sequences had 
similarities with uncultured bacteria, while 5 other sequences had similarities with Rheinheimera sp. The percentage of similarity of DGGE sequences with data on gene bank ranges from $81-99 \%$. Phylogenetic tree analysis used a maximum likelihood tree Tamura 3 parameter model with $1000 \mathrm{X}$ bootstrap. The phylogenetic tree shows the amplified bacteria are phylum proteobacteria consisting of the class of gammaproteobacteria, alfaproteobacteria, and deltaproteobacteria (Figure 5).

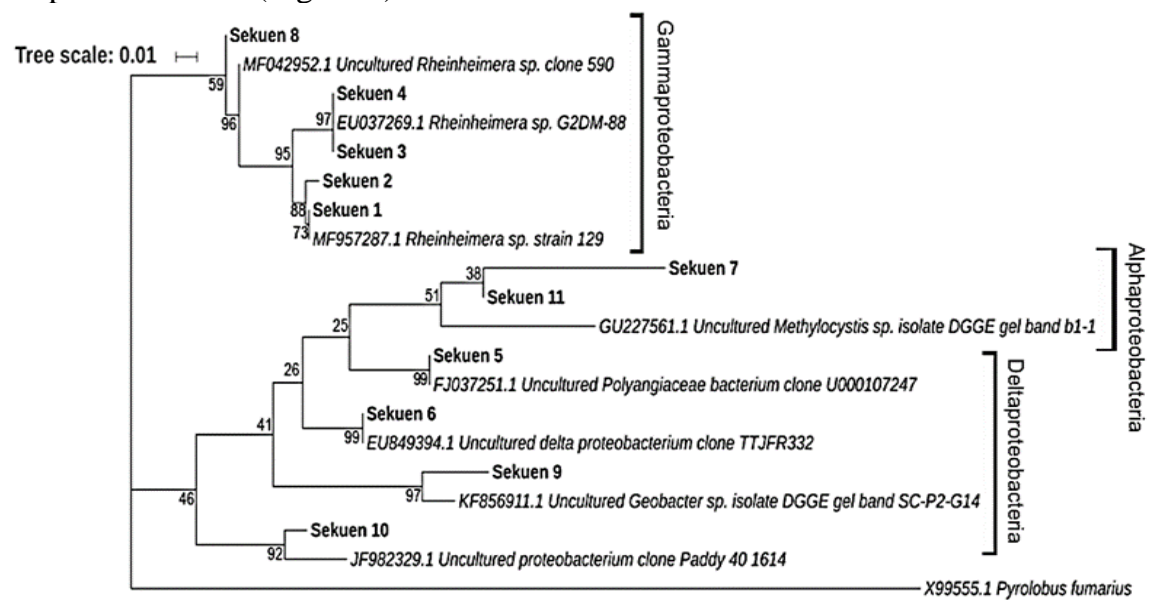

Fig 5. Phylogenetic tree (Maximum Likelihood tree) 16S rRNA using Tamura 3 Model parameters with bootstrap $1000 \mathrm{X}$

DNA extraction produces DNA with relatively low purity, i.e A260/280 values ranging from 0.9-1.6. The low value of A260/280 is caused by DNA being extracted directly from the soil so that there are many impurities. This can be seen from the A260 / 230 value which ranges from 0.3-1.9. Impurity can be humid acid which can be read in waves A230 and A260 [13]. DGGE analysis on each sample from each DAP can separate the analyzed sample into several separate bands. [14] stated that DGGE analysis can separate species based on GC composition, where each sequence will migrate in different positions and produce a band pattern that shows a different taxon. Amplification of the 16S rRNA gene using 338FGC/518R primary pairs [12]. This primer is specific for amplifying the V3 region of $16 \mathrm{~S}$ rRNA that is commonly used in DGGE analysis.

Clustering analysis in the form of a dendrogram showed differences in the similarity between the bacterial communities in each treatment at each DAP. The 30 DAP dendrogram showed NPK fertilization and the combination of NPK with methanotroph had different bacterial diversity compared to the control treatment in the vegetative phase. The P4 and P6 treatments had the highest bacterial diversity, with the highest P1, P2, and P5 treatments. The 60 DAP dendrogram showed that in the early reproductive phase, the combination of NPK fertilization with methanotrophic bacteria had different bacterial diversity from NPK fertilization treatments, and control treatments tended to have the same bacterial diversity as NPK fertilization treatments. P5 and P6 treatments had the highest similarity, followed by treatments P4, P2 and P3, and P1. Dendrogram 90 DAP shows NPK fertilization treatment and NPK fertilization with methanotroph have the same diversity of bacteria in the final phase of maturation, whereas control treatment without fertilization and treatment with methanotroph alone have different bacterial diversity. The treatments P1 and P2 have the highest similarity, followed by treatments P4 and P5, P3, and P6. 
Bacterial diversity at each growth phase shows differences and tends to be influenced by fertilizer application. According to [15] fertilizing which is done to increase the availability of nutrients will cause changes in the composition of the soil and microbial community. A study conducted by [16] shows that $\mathrm{N}$ fertilization can increase soil acidity which results in leaching of several cations such as $\mathrm{mg} 2+, \mathrm{Ca} 2+$, and $\mathrm{Na} 2+$, and mobilization of $\mathrm{Al} 3+$. This causes the growth of microbes to be limited because of the lack of these cations. The diversity of bacteria is also influenced by root exudates. [17] stated that the exudate activity of rice roots is low in the vegetative phase, increases in the generative phase, and decreases in the maturation phase.

BLAST analysis produces several genera that dominate. The genus Rheinheimera has the characteristics of gram-negative, flagella, rod-shaped, and has catalase and oxidase activity [18]. This genus is widely isolated from the marine and estuarine environments, such as R. baltica [18], R. pacifica [19], and R. perlucida [18]. Two species were reportedly isolated from the soil, R. soli BD-d46 [20] and R. tangshanensis JA3-B52 from rice [21]. [22] reported the Rheiheimera isolate produced by metagenome in rice roots that had the nifH gene.

Phylogenetic tree construction shows that phylobacter proteobacteria dominate paddy soil, which consists of classes of gammaproteobacteria, alfaproteobacteria, and deltaproteobacteria. A study conducted by [23] on the diversity of soil rhizosphere bacteria based on the 16S rRNA gene shows that proteobacteria are the most abundant phylum (39\%), of which $18.8 \%$ are of the alfaproteobacteria class, $8.1 \%$ of the gammaproteobacteria class and $2.3 \%$ of deltaproteobacteria.

\section{Conclusion}

Bacterial diversity in the application of methanotrophic bacteria Methylocystis rosea BGM 1, M. palvus BGM 3, Methylococcus capsulatus BGM 9, and Methylobacter sp. SKM 14 in rain-fed rice fields is different in each phase of rice growth. The study of bacterial diversity based on the 16S rRNA gene shows that the genus proteobacteria dominates habitats consisting of classes of gammaproteobacteria, alfaproteobacteria, and deltaproteobacteria.

\section{References}

[1] J. Le Mer and P. Roger, "Production, oxidation, emission and consumption of methane by soils: A review,” Eur. J. Soil Biol., vol. 37, no. 1, pp. 25-50, 2001, doi: 10.1016/S1164-5563(01)01067-6.

[2] R. Conrad and F. Rothfuss, "Methane oxidation in the soil surface layer of a flooded rice field and the effect of ammonium," Biol. Fertil. Soils, vol. 12, no. 1, pp. 28-32, 1991, doi: 10.1007/BF00369384.

[3] W. Hapsary, "Isolasi karakterisasi bakteri metanotrof asal sawah di Bogor dan Sukabumi," 2008.

[4] I. Rusmana and A. Akhdiya, "Isolation and characterization of methanotrophic bacteria from rice fields," Biotropia (Bogor)., vol. 16, no. 2, pp. 71-78, 2009, doi: 10.11598/btb.2009.16.2.53.

[5] A. F. Bintarti, I. Rusmana, and A. T. Wahyudi, "Identification of nif D and nif H Genes of Methanotrophic Bacteria from Rice Field," 2010.

[6] G. M. F. Pingak, H. Sutanto, A. Akhdiya, and I. Rusmana, "Effectivity of Methanotrophic Bacteria and Ochrobactrum Anthropi as Biofertilizer and Emission Reducer of CH4 and N2O in Inorganic Paddy Fields,” J. Med. Bioeng., vol. 3, no. 3, pp. 217-221, 2014, doi: 10.12720/jomb.3.3.217-221.

[7] H. Sutanto, I. Rusmana, and N. R. Mubarik, "Community succession of methanotrophic bacteria based on PMOA GENE in rice fields,” Adv. Environ. Biol., vol. 8, no. 14, pp. 50-56, 2014. 
[8] Sukmawati, I. Rusmana, and N. R. Mubarik, "The effectiveness of methanotrophic bacteria and Ochrobactrum anthropi to reduce CH4and $\mathrm{N} 2 \mathrm{O}$ emissions and to promote paddy growth in lowland paddy fields," Malays. J. Microbiol., vol. 12, no. 1, pp. 50-55, 2016.

[9] R. A. Taopan, I. Rusmana, and D. A. Santosa, "The Effect of Methanotrophic Bacteria Application on Paddy Growth and Methane Emission in Rainfed Rice of Kupang Regency, East Nusa Tenggara, Indonesia," Int. J. Environ. Agric. Biotechnol., vol. 3, no. 5, pp. 1759-1764, 2018, doi: 10.22161/ijeab/3.5.25.

[10] T. Doi, J. Abe, F. Shiots, and S. Morita, "Study on rhizosphere bacterial community in lowland rice grown with organic fertilizers by using PCR-denaturing gradient gel electrophoresis," Plant Root, vol. 5, no. January 2011, pp. 5-16, 2011, doi: 10.3117/plantroot.5.5.

[11] G. Muyzer and K. Smalla, "Application of denaturing gradient gel electrophoresis (DGGE) and temperature gradient gel electrophoresis (TGGE) in microbial ecology," Antonie van Leeuwenhoek, Int. J. Gen. Mol. Microbiol., vol. 73, no. 1, pp. 127-141, 1998, doi: 10.1023/A:1000669317571.

[12] L. Øvreås, L. Forney, F. L. Daae, and V. Torsvik, "Distribution of bacterioplankton in meromictic lake Saelenvannet, as determined by denaturing gradient gel electrophoresis of PCR-amplified gene fragments coding for 16S rRNA,” Appl. Environ. Microbiol., vol. 63, no. 9, pp. 3367-3373, 1997, doi: 10.1128/aem.63.9.3367-3373.1997.

[13] C. Yeates, M. R. Gillings, A. D. Davison, N. Altavilla, and D. A. Veal, "art\%3A10.1251\%2Fbpo6(1).pdf," vol. 1, no. 1.

[14] G. Muyzer, E. C. De Waal, and A. G. Uitterlinden, "Profiling of complex microbial populations by denaturing gradient gel electrophoresis analysis of polymerase chain reaction-amplified genes coding for 16S rRNA," Appl. Environ. Microbiol., vol. 59, no. 3, pp. 695-700, 1993, doi: 10.1128/aem.59.3.695-700.1993.

[15] P. Marschner, D. Crowley, and C. H. Yang, "Development of specific rhizosphere bacterial communities in relation to plant species, nutrition and soil type," Plant Soil, vol. 261, no. 1-2, pp. 199-208, 2004, doi: 10.1023/B:PLSO.0000035569.80747.c5.

[16] K. K. Treseder, "Nitrogen additions and microbial biomass: A meta-analysis of ecosystem studies," Ecol. Lett., vol. 11, no. 10, pp. 1111-1120, 2008, doi: 10.1111/j.1461-0248.2008.01230.x.

[17] M. S. Aulakh, R. Wassmann, C. Bueno, and H. Rennenberg, "Impact of root exudates of different cultivars and plant development stages of rice (Oryza sativa L.) on methane production in a paddy soil," Plant Soil, vol. 230, no. 1, pp. 77-86, 2001, doi: 10.1023/A:1004817212321.

[18] I. Brettar, R. Christen, and M. G. Höfle, "Rheinheimera baltica gen. nov., sp. nov., a blue-coloured bacterium isolated from the central Baltic Sea.," Int. J. Syst. Evol. Microbiol., vol. 52, no. 5, pp. 1851-1857, 2002, doi: 10.1099/00207713-52-5-1851.

[19] L. A. Romanenko, M. Uchino, E. Falsen, N. V. Zhukova, V. V. Mikhailov, and T. Uchimura, "Rheinheimera pacifica sp. nov., a novel halotolerant bacterium isolated from deep sea water of the Pacific," Int. J. Syst. Evol. Microbiol., vol. 53, no. 6, pp. 1973-1977, 2003, doi: 10.1099/ijs.0.02252-0.

[20] S. H. Ryu, B. S. Chung, M. Park, S. S. Lee, S. S. Lee, and C. O. Jeon, "Rheinheimera soli sp. nov., a gammaproteobacterium isolated from soil in Korea," Int. J. Syst. Evol. Microbiol., vol. 58, no. 10, pp. 2271-2274, 2008, doi: 10.1099/ijs.0.65489-0.

[21] X. Zhang, L. Sun, F. Qiu, R. J. C. McLean, R. Jiang, and W. Song, "Rheinheimera tangshanensis sp. nov., a rice root-associated bacterium,” Int. J. Syst. Evol. Microbiol., vol. 58, no. 10, pp. 2420 2424, 2008, doi: 10.1099/ijs.0.65605-0.

[22] J. Prakamhang, K. Minamisawa, K. Teamtaisong, N. Boonkerd, and N. Teaumroong, "The communities of endophytic diazotrophic bacteria in cultivated rice (Oryza sativa L.)," Appl. Soil Ecol., vol. 42, no. 2, pp. 141-149, 2009, doi: 10.1016/j.apsoil.2009.02.008.

[23] P. H. Janssen, "Identifying the dominant soil bacterial taxa in libraries of 16S rRNA and 16S rRNA genes," Appl. Environ. Microbiol., vol. 72, no. 3, pp. 1719-1728, 2006, doi: 10.1128/AEM.72.3.1719-1728.2006. 